\title{
THE EFFICIENCY CONSEQUENCES OF LOCAL REVENUE EQUALIZATION: TAX COMPETITION AND TAX DISTORTIONS
}

\author{
SAM BUCOVETSKY \\ MICHAEL SMART \\ CESIFo Working PAPER No. 767 \\ CATEGory 1: PUBlic FinANCE \\ August 2002
}

An electronic version of the paper may be downloaded

- from the SSRN website: www.SSRN.com

- from the CESifo website: www.CESifo.de 


\title{
THE EFFICIENCY CONSEQUENCES OF LOCAL REVENUE EQUALIZATION: TAX COMPETITION AND TAX DISTORTIONS
}

\begin{abstract}
This paper shows how a popular system of federal revenue equalization grants can limit tax competition among subnational governments, correct fiscal externalities, and increase government spending. Remarkably, an equalization grant can implement efficient policy choices by regional governments, regardless of a wide variety of differences in regional tax capacity, tastes for public spending, and population. Thus, compared to other corrective devices, equalization achieves "robust" implementation. If aggregate tax bases are elastic, however, equalization leads to excessive taxation. Efficiency can be achieved by a modified formula that equalizes a fraction of local revenue deficiencies equal to the fraction of taxes that are shifted backward to factor suppliers.
\end{abstract}

JEL Classification: H7.

Keywords: tax competition, intergovernmental grants.

\author{
Sam Bucovetsky \\ Department of Economics \\ York University \\ 4700 Keele Street \\ Toronto, Ontario \\ Canada \\ sam@dept.econ.yorku.ca
}

\author{
Michael Smart \\ University of Toronto \\ 150 St. George St. \\ Toronto ON M5S $3 G 7$ \\ Canada \\ msmart@economics.utoronto.ca
}

Thanks to Jean Hindriks, Mats Persson, Torsten Persson, and other seminar participants for comments. 


\section{Introduction}

Decentralization of spending powers to lower-level governments is a widespread phenomenon, one which appears to have become more common in recent years. The benefits of decentralization are familiar to economists, at least since the work of Tiebout (1956). Decentralization has often been held to increase the responsiveness of policy to the preferences of citizens, and to increase accountability in government. Some of the costs of decentralization are also familiar. ${ }^{1}$ If government spending must be financed from local fiscal resources, then it is apt to be distributed unequally among regions. But decentralization is known to have potentially negative consequences for efficiency as well as equity. When tax bases are mobile among regions in a federation, then uncoordinated local policy-making may exert downward pressure on government spending everywhere, distorting the mix of public and private consumption. Further, unharmonized local policies can distort the allocation of mobile resources among regions, which leads to failures of production efficiency. These and a variety of other fiscal spillovers among regions can make outcomes Pareto inefficient in a decentralized federation.

A variety of reforms have been proposed to correct these different problems associated with decentralization. In this paper, we argue that one simple mechanism available to federal governments-equalization grants-can in a wide variety of circumstances address both the efficiency and equity problems of decentralization.

An equalization grant is a particular system of federal revenue sharing that is already employed in a number of countries. ${ }^{2}$ In its idealized form, an equalization system sets the (per capita) transfer to each government equal to the difference between its measured tax capacity and the average capacity of all regions, multiplied by some "standard" tax rate, usually equal to the average of all regions' tax rates. Thus the program aims to equalize differences in tax revenue, but implements transfers through an indirect formula, based on differences in observed tax bases. The use of the standard tax rate accommodates diversity in lower-level governments' spending patterns: ideally, equalization makes differences in local tastes, rather than in local fiscal capacity, the only cause of differences in local public spending.

That equalization can make the regional distribution of public goods more equitable should be clear. Indeed, when all governments choose the same tax rate, the formula guarantees equal per capita net revenues. The impact of the formula on efficiency of tax policies in a world of mobile tax bases is more subtle, but still straightforward. A tax cut by a single region causes an inflow of the tax base to the region, which mitigates the revenue loss of the tax cut, but at the expense of government revenues in other regions; this fiscal externality is the principal source of the inefficiency. But the increase in tax base relative to the national average also reduces the deviating government's entitlement under an equalization formula. This offsets the impact of the tax cut on own-source revenue, and so tends to increase equilibrium "tax effort" of all regions. In fact, in a central case, we are able to show that the equalization effect exactly offsets the fiscal externality, making regional governments willing to implement the tax policies that would be chosen by a unitary central government.

To make this point, we lay out a popular theory of local capital tax competition and consider the effects of equalization grants on Nash equilibrium tax rates. ${ }^{3}$ In the canonical version of the

\footnotetext{
${ }^{1}$ Oates (1972) is probably the best-known elaboration of the trade-offs involved in allocation of taxing and spending powers to different levels of government.

${ }^{2}$ These include Canada, Denmark, Sweden, Switzerland, and a large number of developing countries. As well, the equalization formula is the basis of local school district finance in a number of US states (Card and Payne, 2002).

${ }^{3}$ The model is originally due to Wilson (1986) and Zodrow and Mieszkowski (1986). Here we consider an expanded
} 
model, capital is in fixed supply to the nation as a whole, but mobile among regions; thus Nash equilibrium tax rates lie below the level that would be chosen by a unitary central government. In this environment, we show that an equalization grant induces regional governments to set tax rates efficiently, while simultaneously equalizing revenue among the regions. Thus equalization decentralizes a central government's preferred allocation.

Of course, many federal grant systems other than equalization could also be designed to achieve the optimum; all that must be done is to set the slope of the transfer formula to correct regional governments' incentives, and to set the intercept to equalize spending appropriately. Thus, for example, Wildasin (1991) proposes a system of linear matching grants for local tax rates, and Figuieres, Hindriks and Myles (2001) a transfer system that pools a fraction of local revenues and shares it equally among all governments. What is noteworthy about our result is that a simple equalization formula decentralizes the optimum in a rich set of environments, regardless of the degree of regional mobility of capital, and regardless of a variety of differences in the tax capacities and populations of regional governments and the tastes of residents for public spending. Thus equalization achieves "robust" implementation where other grant formulas do not. The simplicity of the formula is an attractive feature of equalization, especially when differences among regions are large and variable over time-which seems to be precisely when such grants are most often observed in practice.

So far, our results deal with the case of a fixed national tax base that is mobile among regions. But taxes generally have distortionary effects at the national as well as regional level. We therefore consider an extended version of the model, in which capital is elastically supplied by consumers, and we show that full equalization leads to equilibrium tax rates higher than optimal. Even in this case, however, a simple fix is available: the optimum can be decentralized by a system of "partial" equalization that compensates regions for a proper fraction of differences in revenue capacity. The optimal fraction is equal to the fraction of coordinated national tax increases that is shifted backward to capital owners, a parameter that can be easily estimated. Moreover, the optimal formula is the same for all jurisdictions, regardless of differences in local tax capacity, tastes, or population.

Our results have important antecedents in the literature. Smart (1998) shows how an equalization grant induces inefficiently high tax rates on a tax base that is elastically supplied but immobile among regions. The direction of the effect in this paper is the same but, because of regional mobility, the normative implications are quite different. The general notion that federal revenue sharing can align local government incentives and reduce tax competition is much older, and is discussed by Brennan and Buchanan (1980), among others. Boadway and Hayashi (2001) and Esteller-Moré and Solé-Ollé (2002) provide evidence that equalization has reduced business tax competition among provincial governments in Canada. Köthenbürger (2002) also establishes our basic result for the case of identical regions and fixed aggregate capital supply. Here we extend the analysis to elastic tax bases and show how the effects of equalization are robust to regional inequality and differences in tastes and population.

The plan of the paper is as follows. Section 2 presents the model, describes the Nash equilibrium, and characterizes transfer systems that implement the central government's optimum. Section 3 shows how equalization decentralizes the central optimum when the national aggregate tax bases are fixed. Section 4 extends the argument to elastic tax bases and to regional population differences. Section 5 concludes the paper.

version of the model that incorporates (elastic) savings behaviour, as in Keen and Kotsogiannis (2001). 


\section{A model of tax competition in a federation}

A federal economy consists of $N$ regions. In each region, firms produce a single, homogeneous consumption good with a linear-homogeneous technology, using an immobile factor, land, and a mobile factor, capital. Since the land input is fixed in each region, we suppress it from notation and write the aggregate production of region $i$ as $f_{i}\left(k_{i}\right)$, if $k_{i}$ units of capital are employed there. Capital is paid its marginal product, and residual returns $\pi_{i}\left(k_{i}\right)=f_{i}\left(k_{i}\right)-k_{i} f_{i}^{\prime}\left(k_{i}\right)$ accrue to landowners. (The consumption good is the numeraire.)

A single representative citizen resides in each region and is endowed with all of the local land input and $B$ units of the consumption good. The agent consumes at two dates, both before and after production takes place. Thus the agent elastically supplies $s_{i}$ units of the good for use as capital by firms, while consuming the balance $c_{i}^{1}=B-s_{i}$ in the first period. Capital moves freely among regions in the federation and is allocated to maximize returns to capitalists. Accordingly, in equilibrium, it earns an equal net rate of return $r$ in each jurisdiction, and agents receive total factor incomes

$$
c_{i}^{2}=\pi_{i}\left(k_{i}\right)+(1+r) s_{i}
$$

which are available for consumption in the second period. (Observe that there are by assumption no residence-based income taxes in the economy.) Each local government levies a specific, source-based tax $t_{i}$ on capital employed in the jurisdiction to finance spending on the local public good. Citizens in all jurisdictions have quasi-linear preferences over bundles of public and private consumption $u\left(c_{i}^{1}\right)+c_{i}^{2}+b_{i}\left(g_{i}\right)$, where $g_{i}$ is the quantity of a local public good provided in $i$, and each $b_{i}$ is a strictly concave function.

To describe market equilibrium, let

$$
v\left(k_{i}, r\right)=\max _{s}\left\{u(B-s)+c_{i}^{2}: c_{i}^{2}=\pi_{i}\left(k_{i}\right)+(1+r) s\right\}
$$

represent the indirect utility of agent $i$ from private consumption, and let $s(r)$ be the associated utility-maximizing supply of capital. Observe that, because preferences are quasi-linear, optimal saving is independent of income and so is independent of domestic investment and land rents.

Firms in each jurisdiction choose investment to maximize profit, taking the gross cost of capital $r+t_{i}$ as given; thus each region's capital demand function is defined by the usual marginal condition

$$
k_{i}=\phi_{i}\left(r+t_{i}\right) \Longleftrightarrow f_{i}^{\prime}\left(k_{i}\right)=r+t_{i}
$$

Observe that $\phi_{i}^{\prime}\left(r+t_{i}\right)=1 / f_{i}^{\prime \prime}\left(k_{i}\right)<0$. Let $S(r)=N s(r)$ denote the aggregate supply function for capital in the federation. Given tax rates $t=\left(t_{1}, \ldots, t_{N}\right)$, the capital market in this economy clears at an interest rate $r^{*}(t)$ such that

$$
\sum_{i} \phi_{i}\left(r^{*}+t_{i}\right)=S\left(r^{*}\right)
$$

which in turn yields the equilibrium investment levels $k_{i}^{*}(t)=\phi_{i}\left(r^{*}(t)+t_{i}\right)$. Implicit differentiation of yields the comparative static derivatives

$$
\begin{gathered}
\frac{\partial r^{*}}{\partial t_{i}}=\frac{\phi_{i}^{\prime}\left(r^{*}+t_{i}\right)}{S^{\prime}(r)-\sum_{j} \phi_{j}^{\prime}\left(r+t_{j}\right)}<0 \\
\frac{\partial k_{i}^{*}}{\partial t_{i}}=\phi_{i}^{\prime}\left(r+t_{i}\right)\left(1+\frac{\partial r^{*}}{\partial t_{i}}\right)<0
\end{gathered}
$$

and 


$$
\frac{\partial k_{j}^{*}}{\partial t_{i}}=\phi_{j}^{\prime}\left(r+t_{j}\right) \frac{\partial r^{*}}{\partial t_{i}}>0 j \neq i
$$

Thus a unilateral tax increase in jurisdiction $i$ causes a decline in the equilibrium interest rate, and investment declines at home but rises elsewhere.

\subsection{Nash equilibrium}

Local governments are assume to behave non-cooperatively, using the source-based tax rates $t_{i}$ as their strategic variables. They also respond to a transfer formula chosen by a central government. The timing of events is : first, the central government commits to a transfer formula $T_{i}\left(t_{1}, t_{2}, \cdots, t_{N}\right)$ defining the net transfer to each jurisdiction as a function of the tax rates; second the jurisdictions choose their tax rates $t_{i}$ simultaneously; third, consumers and firms make their saving and investment decisions; fourth, production and consumption take place. The quantity of public goods provided in jurisdiction $i$ is

$$
g_{i}=t_{i} k_{i}^{*}(t)+T_{i}(t)
$$

Each jurisdiction's government chooses its tax rate so as to maximize the utility of its citizens, $\left.v\left(k_{i}^{*}(t), r^{*}(t)\right)+b_{i}\left(g_{i}\right)\right)$ subject to the budget constraint (7), taking as given the other jurisdictions' tax rates, and the central government's transfer formula. The first-order condition for this problem is

$$
k_{i}^{*}+\left(k_{i}^{*}-s\right) \frac{\partial r^{*}}{\partial t_{i}}=b_{i}^{\prime}\left(g_{i}\right)\left[k_{i}^{*}+t_{i} \frac{\partial k_{i}^{*}}{\partial t_{i}}+\frac{\partial T_{i}}{\partial t_{i}}\right]
$$

The left side of equation (8) is the marginal cost, in reduced consumption of the private good (in the second period), of a tax increase in the jurisdiction. The right side is the marginal benefit of the increase in public good consumption resulting from the tax increase. ${ }^{4}$ Note that the transfer formula will tend to encourage tax effort if the size of the transfer received by the jurisdiction increases with the jurisdiction's tax rate.

\subsection{Optimal taxes in a unitary state}

As a benchmark, consider the optimum for a central government which could set each jurisdiction's tax rate directly, and which could allocate this tax revenue for public good provision in each jurisdiction. However the central government is not allowed to transfer income in a lump-sum fashion among jurisdictions. If each jurisdiction had the same population, and if the central government wished to maximize the sum of people's utilities in the federation, then it would choose the tax rates to maximize

$$
\sum_{i}\left[v_{i}\left(k_{i}^{*}, r^{*}\right)+b_{i}\left(g_{i}\right)\right]
$$

subject to the consolidated national budget constraint

$$
\sum_{i} g_{i}=\sum_{i} t_{i} k_{i}^{*}
$$

The unitary optimum is therefore described by the first-order conditions

$$
b_{i}^{\prime}\left(g_{i}\right)=\mu
$$

\footnotetext{
${ }^{4}$ The left side of the equation must be positive, since equation (4) shows that $\partial r^{*} / \partial t_{i}$ must be less than 1 in absolute value. Therefore, if $t_{i}$ is a best response for jurisdiction $i$, then the right side must be positive as well.
} 
and

$$
k_{i}=\mu\left(k_{i}+\sum_{j} t_{j} \frac{\partial k_{j}^{*}}{\partial t_{i}}\right)
$$

where $\mu$ is the Lagrange multiplier on the consolidated government budget constraint (9).

The first condition implies that the marginal benefit of the public good is equalized in all jurisdictions; when preferences for the public good are identical among regions, this implies uniform provision as well. The second condition (11) implies equalization of the marginal deadweight loss of each region's source-based tax $t_{i}$; in particular, each regional government must internalize the (positive) effect of tax increases on revenues in other jurisdictions.

Comparing (13) and (6) gives a decomposition of the externalities that each jurisdiction's tax policy imposes on the others: if an intergovernmental transfer system $T^{*}$ decentralizes the centralized optimum allocation, then

$$
\frac{\partial T_{i}^{*}}{\partial t_{i}}=\sum_{j \neq i} t_{j}^{*} \frac{\partial k_{j}^{*}}{\partial t_{i}}+\frac{1}{b^{\prime}(g)} \frac{\partial r^{*}}{\partial t_{i}}\left(k_{i}-s\right)
$$

This transfer system implements a marginal subsidy to local tax collections that has a Pigouvian interpretation. The first term in (12) is the external effect of a tax increase in $i$ on revenues collected in other jurisdictions $j \neq i$, identified in Wildasin (1989). The second term, discussed in DePater and Myers (1994), is the "terms of trade" effect of a tax increase on net capital income in region $i$; this effect is positive for a net capital importer and negative for a net exporter. Since exports from one jurisdiction equal imports by all others, the marginal terms of trade gain to the home jurisdiction equals the marginal damage imposed on the others, and the Pigouvian subsidy offsets this pecuniary external effect as well.

\subsection{Equalization grants}

Equalization grants represent a particular form of transfer. In its idealized form, an equalization grant system would ensure that each jurisdiction would provide the average level of public goods for the federation, were the jurisdiction to levy the national average tax rate. This system, which we will call "full equalization," therefore implies a transfer of

$$
T_{i}^{E}=\bar{t}\left(\bar{k}-k_{i}\right)
$$

where the national average tax rate is

$$
\bar{t} \equiv \frac{\sum_{j} t_{j} k_{j}}{\sum_{j} k_{j}}
$$

and the national average tax base is

$$
\bar{k} \equiv \frac{\sum_{j} k_{j}}{N}
$$

If $R \equiv \sum t_{j} k_{j}$ denotes the total tax revenue in the federation, and $K \equiv \sum k_{j}$ the total capital demand in the federation, then equation (13) can be written

$$
T_{i}^{E}=R\left(\frac{1}{N}-\frac{k_{i}}{K}\right)
$$


Thus equalization pays each jurisdiction a fraction of national revenues equal to the difference between its population share and its share of the tax base. In what follows, we will also consider a system of partial equalization, in which a fraction $\alpha$ of differences in local revenue capacity are equalized, so that $T_{i}=\alpha T_{i}^{E}$.

To understand how equalization affects each government's incentives in setting taxes, it is useful to consider the marginal change in transfers resulting from a local tax increase. Differentiation of equation (14) yields

$$
\frac{\partial T_{i}^{E}}{\partial t_{i}}=\left(\frac{1}{N}-\frac{k_{i}}{K}\right) \frac{\partial R}{\partial t_{i}}-\frac{R}{K}\left(\frac{\partial k_{i}^{*}}{\partial t_{i}}-\frac{k_{i}}{K} \frac{\partial K}{\partial t_{i}}\right)
$$

Comparing the marginal incentives under equalization to the optimal grant system (12) is our focus in most of what follows.

\section{Efficient equalization: The fixed saving case}

Inspection of the marginal equalization grant in (15) leaves the effects of transfer far from clear and, comparing the optimal grant in (12), it may seem surprising that equalization can decentralize optimal local taxes. To show why this is indeed the case, we first consider some simpler cases. Assume that per capita saving $s(r)$ is independent of the net return $r$, so that the total quantity of capital employed, $K \equiv \sum_{j} k_{j}^{*}$ is also fixed in equilibrium. This is sufficient to guarantee that the optimal tax system is uniform across jurisdictions, so that the allocation of capital achieves production efficiency. ${ }^{5}$ Thus we have:

Lemma 1 When saving is inelastic, the unique unitary optimum $\left(t_{i}^{*}, g_{i}^{*}\right)$ has

$$
b_{i}^{\prime}\left(g_{i}^{*}\right)=1
$$

and

$$
t_{i}^{*}=t^{*} \equiv S /\left(\sum_{j} g_{j}^{*}\right)
$$

Proof. See the appendix.

It should be clear that the policy described in the lemma satisfies the first-order conditions (10)-(11) for optimality; the proof also shows that this is an optimal policy, and that it is the only optimal policy.

Can this optimum be implemented by an equalization grant? The answer is yes. To understand why this is the case, first consider an example in which all jurisdictions have identical production technologies and preferences for the public good. (This is the environment considered by Köthenbürger (2002).) Since Lemma 1 implies optimal taxes are uniform $\left(t_{i}=t^{*}\right)$, and since technologies are identical, the equilibrium capital allocation is symmetric: $k_{i}=K / N$ for all $i$. The marginal equalization grant in (15) then simplifies to

$$
\frac{\partial T_{i}^{E}}{\partial t_{i}}=-t^{*} \frac{\partial k_{i}^{*}}{\partial t_{i}}
$$

\footnotetext{
${ }^{5}$ The unitary optimum does not generally involve production efficiency, however: a national government may prefer to distort the allocation of capital among regions in order to redistribute consumption among local residents. We return to this point below.
} 
Faced with an equalization grant, each jurisdiction sets its tax rate to satisfy the first-order condition (8), which simplifies to

$$
k_{i}=b^{\prime}\left(g_{i}\right) k_{i}
$$

Moreover, symmetry implies $g_{i}=t^{*} K / N$ for each jurisdiction; thus (16) coincides with the firstorder condition (12) describing the unitary optimum tax rate. Therefore, full equalization yields a Nash equilibrium to the tax-setting game played by the jurisdictions, in which they all choose the optimal tax rates, and spend the optimal amount on the public good.

In this case, since the equilibrium is symmetric, no transfers are actually paid in equilibrium. Nevertheless, a deviation by any regional government from the optimal tax rate would induce a change in transfers that exactly offsets the "base" effect of the tax change $t^{*} \partial k_{i}^{*} / \partial t_{i}$. Thus each government optimally behaves as though its tax base were independent of the local tax rate; since the national base is indeed perfectly inelastic, this induces optimal tax policies.

In reality, equalization grants are typically paid when there are substantial differences in local tax capacities; it is undoubtedly regional inequality, rather than tax competition, that typically motivates the transfers. It therefore seems important to incorporate regional inequality into the analysis. The following result shows that the corrective effect of equalization is robust to (a form of) differences in regional investment demands. We assume that regional capital demands are of the multiplicative form $\phi_{i}(\rho)=A_{i} \phi(\rho)$ for some parameters $A_{i}$; this guarantees that the elasticity of tax bases is the same in all regions, even though the level of tax bases may differ. The following result shows that equalization decentralizes the optimal tax system in this case, regardless of the distribution of regional productivity levels $A_{i}$.

Proposition 1 Suppose that saving is perfectly inelastic, all jurisdictions have identical preferences for the public good $b\left(g_{i}\right)$, and regional capital demand functions satisfy

$$
\phi_{i}(\rho)=A_{i} \phi(\rho)
$$

for some parameters such that $\sum_{i} A_{i}=N$ and some function $\phi$. Then full equalization implements the unitary optimum.

Proof. Since saving is inelastic, the unitary optimal policy sets $\mu=b^{\prime}\left(g_{i}\right)=1$ for all $i$. Since optimal taxes are uniform, (12) implies a transfer formula will implement the optimum only if

$$
\frac{\partial T_{i}^{*}}{\partial t_{i}}=-t^{*} \frac{\partial k_{i}^{*}}{\partial t_{i}}+\frac{\partial r^{*}}{\partial t_{i}}\left(k_{i}-s\right)
$$

whereas the marginal equalization grant is

$$
\frac{\partial T_{i}^{E}}{\partial t_{i}}=-t^{*} \frac{\partial k_{i}^{*}}{\partial t_{i}}-\frac{1}{K} \frac{\partial R}{\partial t_{i}}\left(k_{i}-s\right)
$$

But, since saving is inelastic, $\partial R / \partial t_{i}=k_{i}$, and (4) implies

$$
\frac{\partial r^{*}}{\partial t_{i}}=-\frac{A_{i}}{N}=-\frac{k_{i}}{K}
$$

where the last equality uses the multiplicative form of productivity differences (17). Finally, observe that when tax rates are uniform transfers equalize government spending in all jurisdictions to $g_{i}=t^{*} K / N$. Thus equalization decentralizes the unitary optimal policies. 
It is perhaps not particularly surprising that a revenue sharing program, if correctly designed, can cause local governments to account for the externality their decisions about tax rates impose on the revenues accruing to other governments. But the problem in this environment is more complex: in addition to the fiscal externality, local tax policies are distorted by the pecuniary externality among regions. Because local tax cuts exert some positive effect on the rate of return to capital in the nation, low-productivity, capital exporting regions prefer lower capital taxes than do high-productivity, capital importing regions. This effect is independent of the direct effect of tax cuts on local tax bases and on government revenues. Nevertheless, the proposition shows that an equalization grant causes regional governments to internalize the pecuniary externality as well.

Of course, any grant system which achieved the appropriate "Pigouvian" marginal subsidy to local tax collections, as described by (12), and which equalized the marginal benefit of the public good in all regions, would decentralize the unitary optimum. Thus an equalization grant does not uniquely implement the optimum. For example, Figuieres, Hindriks and Myles (2001) show how the optimum can be achieved through a grant system which pooled a particular fraction of local tax revenues and redistributed it on an equal per capita basis. ${ }^{6}$ But decentralization through revenue pooling requires the federal government to observe the elasticity of local tax base function $\phi$ and to set the share of revenues to be pooled appropriately; equalization achieves the optimum more parsimoniously. When regional tax bases are unequal, moreover, an optimal system of revenue pooling would require the grant formula to be differentiated among regions, whereas equalization is robust to regional inequality.

In the model presented here, it has been assumed that tax rates are the strategic variables in the non-cooperative game played by regional governments. It is known that the Nash equilibrium allocation is in general sensitive to whether regional governments conjecture that other regions are holding tax rates constant, or holding the level $g_{j}$ of public expenditure constant, or some combination of the two. Figuieres, Hindriks and Myles (2001) have shown that the appropriate central government remedy will differ in each of these cases as well. However, a virtue of the equalization formula $T_{i}^{E}$ is that, when regions are identical and saving is fixed, its efficiency does not depend on the choice of strategic variable by the regions. This invariance is the consequence of the fact that marginal changes in one region's tax rate have no effect at all on the budget constraint faced by any other region. To see this, differentiate the regional budget constraint (7) to obtain

$$
\frac{\partial g_{i}}{\partial t_{j}}=t_{i} \frac{\partial k_{i}^{*}}{\partial t_{j}}+\bar{t}\left[\frac{\partial \bar{k}}{\partial t_{j}}-\frac{\partial k_{i}}{\partial t_{j}}\right]+\frac{\partial \bar{t}}{\partial t_{j}}\left[\bar{k}-k_{i}^{*}\right]=\bar{t} \frac{\partial \bar{k}}{\partial t_{j}}
$$

since $t_{i}=\bar{t}$ and $\bar{k}=k_{i}^{*}$ at the optimum, if regions are identical. Thus fiscal spillovers are absent under full equalization, if $\bar{k}$ is fixed. Because marginal changes in region $j$ 's tax rate do not affect any other region's budget constraint, region $j$ 's conjectures about the other regions' behaviour do not matter: whatever the conjecture, deviations by region $j$ would have no effect on the levels of the strategic variables chosen by the other regions.

Furthermore, equalization decentralizes the unitary optimum even in cases where the central government lacks sufficient information to impose optimal taxes directly. In the environment of Proposition 1, suppose that willingness to pay for the public good $b\left(g_{i}\right)$ were common to all regions and observed by regional but not federal authorities. ${ }^{7}$ Since the optimal tax rate satisfies $b^{\prime}\left(t^{*} K / N\right)=1$, achieving the optimum requires local information. Since the marginal subsidy provided by the equalization grant is scaled automatically by the average tax rate of all jurisdic-

\footnotetext{
${ }^{6}$ They consider fiscal competition for mobile workers rather than capital, but the model is formally equivalent.

${ }^{7}$ See Bucovetsky, Marchand and Pestieau (1998) for a full model along these lines.
} 
tions, an equalization grant is an indirect mechanism achieving (Bayesian) implementation of the unitary optimum.

\section{Partial equalization: The variable saving case}

\subsection{The main result}

Our previous results show that, when the national tax base in perfectly inelastic, an equalization grant decentralizes the optimum by compensating regional governments for increasing tax rates in such a way that they behave as if their own tax bases were inelastic, despite regional mobility of capital. But even coordinated national increases in capital tax rates have distortionary effects, when saving is elastically supplied. Can equalization provide the right incentives for regional governments in this environment?

When $s^{\prime}(r)>0$, characterizing optimal policies is more complicated, and tax rates need not be uniform in general. Manipulating the first-order conditions (11) for the planner's problem gives the following "inverse elasticity" expression for optimal tax rates.

Lemma 2 At the utilitarian optimum allocation, if $s^{\prime}\left(r^{*}\right)>0$, local tax rates satisfy

$$
t_{i}^{*}=\frac{\mu-1}{\mu}\left(\frac{s\left(r^{*}\right)}{s^{\prime}\left(r^{*}\right)}-\frac{\phi_{i}\left(r^{*}+t_{i}^{*}\right)}{\phi_{i}^{\prime}\left(r^{*}+t_{i}^{*}\right)}\right)
$$

where $\mu=b^{\prime}\left(g_{i}^{*}\right)$ for all $i$.

Proof. See the appendix.

When regional productivity differences take the multiplicative form (17), it is immediate from (19) that a uniform tax system again satisfies the first-order conditions. Under an additional condition, it can be shown that the optimum involves tax rates that are uniform across jurisdictions: Suppose that the capital demand function $\phi$ is log-concave (i.e. $\phi^{\prime} / \phi$ is a non-increasing function). ${ }^{8}$ Then

$$
-\frac{\phi\left(r+t_{i}\right)}{\phi^{\prime}\left(r+t_{i}\right)} \leq-\frac{\phi\left(r+t_{j}\right)}{\phi^{\prime}\left(r+t_{j}\right)}
$$

whenever $t_{i} \geq t_{j}$. It follows that $t_{i}^{*}=t_{j}^{*}$ at any solution to (19). ${ }^{9}$

When saving is elastically supplied, full equalization tends to "oversubsidize" local tax increases and hence to result in equilibrium tax rates higher than optimum levels. To see this, consider again the case of identical regions. At any uniform tax system, the marginal equalization grant in (15) is

$$
\frac{\partial T_{i}^{E}}{\partial t_{i}}=-t\left(\frac{\partial k_{i}^{*}}{\partial t_{i}}-\frac{1}{N} \frac{\partial K}{\partial t_{i}}\right)
$$

\footnotetext{
${ }^{8}$ This condition will hold if the Hicks-Allen elasticity of substitution $\sigma$ between capital and land in production (defined so as to have a positive sign) is a non-decreasing function of the cost of capital $\rho$, and if $\sigma$ is everywhere less than or equal to 1 .

${ }^{9}$ If $\phi$ were not log-concave, then there would still exist a solution to the central government's first-order conditions involving equal tax rates. However, there would be no guarantee that every solution to those conditions must have equal tax rates.
} 
so that equilibrium tax rates satisfy

$$
\frac{1-b^{\prime}(g)}{b^{\prime}(g)} K=t \frac{\partial K}{\partial t_{i}}
$$

whereas the optimum requires

$$
\frac{1-b^{\prime}(g)}{b^{\prime}(g)} K=N t^{*} \frac{\partial K}{\partial t_{i}}
$$

Since $K$ is decreasing in $t_{i}$, equilibrium tax rates must exceed optimal levels. This echoes the results in Smart (1998).

Nevertheless, a simple régime of partial equalization can decentralize the optimum in this more general case, where the fraction of revenues to be equalized depends (only) on the semielasticities of capital demand and supply, viz.

$$
\begin{aligned}
& e_{d}=-\frac{\phi^{\prime}(r+t)}{\phi(r+t)} \\
& e_{s}=\frac{s^{\prime}(r)}{s(r)}
\end{aligned}
$$

(Note that by convention these are measured as non-negative numbers.)

Proposition 2 Suppose regional productivity differences take the multiplicative form (17). The unitary optimum can be decentralized by a system of partial equalization grants $T_{i}=\alpha^{*} T_{i}^{E}$, in which a fraction

$$
\alpha^{*} \equiv \frac{e_{d}}{e_{d}+e_{s}}
$$

of capacity differences are equalized, together with a system of lump-sum grants

$$
T_{i}^{0}=g_{i}^{*}-\alpha^{*} T_{i}^{E}\left(t^{*}\right)
$$

Proof. See the appendix.

To interpret the result, note that the expression for $\alpha^{*}$ is equal to

$$
\sum_{i} \frac{\partial r^{*}}{\partial t_{i}}
$$

which is the fraction of coordinated national tax increases that are shifted backward to capital owners in equilibrium. The greater the degree of backward tax incidence, the less distortionary is the tax, and the higher the optimal rate of partial equalization. A particular implication of Proposition 2 is that, when capital is in perfectly elastic supply to the nation (the small open economy case), equalization grants should not be paid.

\subsection{General technologies - and many regions}

Suppose now that regional productivity differences do not take the particular multiplicative form specified in (17). It need not be true that each region should levy the same tax rate, and it need not be true that the equalization formula must be uniform, at the rate $\alpha^{*}$. 
Equation (19) still characterizes the utilitarian optimum. The question addressed in this section is what form of equalization grant will implement the optimal tax rule (19) in this general case.

It will be assumed here that there are a fixed number $M$ of production functions, where the number $M$ may be arbitrarily large, but is finite. Each of the $N$ regions has a production function drawn from this set of $M$ possible functions. Each of the regions has the same population, 1, the same endowment $B$ of the consumption good, and the same quasi-linear preferences $u\left(c^{1}\right)+c^{2}+$ $b(g)$ for its residents. In this section, "small" regions will be considered, by increasing the number $N$ of regions. (The number $M$ of possible technologies will be held fixed, just as the number of types of consumer is held constant when the number of consumers is increased, as in much of the literature on core equivalence in large exchange economies.)

The optimal transfer system must satisfy condition (12), as before. However, as the number of regions grows large, $\partial r^{*} / \partial t_{i}$ approaches zero in (4), and the second term vanishes from the optimal equalization formula: Since small regions cannot affect the terms of trade for capital imports, a utilitarian central government need not correct for the pecuniary externality. On the other hand, the fiscal externality is bounded above zero and, for any $N$, is equal to

$$
\frac{\phi_{i}^{\prime}}{N s^{\prime}-\sum \phi_{j}^{\prime}} \sum_{j \neq i} t_{j}^{*} \phi_{j}^{\prime}
$$

Now, let

$$
\tilde{t}=\lim _{N \rightarrow \infty} \frac{\sum_{j} t_{j}^{*} \phi_{j}^{\prime}}{\sum_{j} \phi_{j}^{\prime}}
$$

which is an average of the regions' tax rates, weighted now not by capital demands, but by their derivatives $\phi_{j}^{\prime}$, and let

$$
\alpha^{*}=\lim _{N \rightarrow \infty} \frac{-\sum_{j} \phi_{j}^{\prime} / N}{s^{\prime}-\sum_{j} \phi_{j}^{\prime} / N} \equiv \frac{\bar{e}_{d}}{e_{s}+\bar{e}_{d}}
$$

where $\bar{e}_{d}$ is here defined as (minus) the semi-elasticity of aggregate capital demand $\sum \phi_{j}$. Rearranging in (20) and taking limits then gives

$$
\frac{\partial T_{i}^{*}}{\partial t_{i}} \rightarrow-\alpha^{*} \tilde{t} \phi_{i}^{\prime}\left(r^{*}+t_{i}^{*}\right) \quad \text { as } N \rightarrow \infty
$$

What of incentives for small regions under an equalization grant $T_{i}^{E}=\bar{t}\left(\bar{k}-k_{i}\right)$ ? Analogous arguments show that the marginal effect of $t_{i}$ on the average tax rate $\bar{t}$ and average tax base $\bar{k}$ vanish as $N$ grows large. Hence, in the limit,

$$
\frac{\partial T_{i}^{E}}{\partial t_{i}} \rightarrow \bar{t} \phi_{i}^{\prime}\left(r+t_{i}\right)
$$

Comparison of equations (21) and (22) then gives the limiting result:

Proposition 3 As the number of regions $N$ grows large, the formula which implements the utilitarian optimum approaches partial equalization of tax bases at the same rate in all regions, with that rate equal to $\alpha^{*} \tilde{t} / \bar{t}$. 
When regional inequalities in productivity take an arbitrary form, and capital is elastically supplied, then the central planner typically prefers regional governments to levy non-uniform tax rates. Nevertheless, the optimum can be decentralized, at least asymptotically, by a uniform system of equalization grants. The fraction of revenues to be equalized is however smaller than in the case of uniform taxes. From the central planner's optimality condition (19), regions with low tax rates have high absolute values of $\phi_{j}^{\prime} / \phi_{j}$, so that

$$
\tilde{t}=\frac{\sum t_{j}^{*} \phi_{j}^{\prime}}{\sum \phi_{j}^{\prime}} \leq \frac{\sum t_{j}^{*} \phi_{j}}{\sum \phi_{j}}=\bar{t}
$$

In this sense, greater inequality among regions undermines the case for tax base equalization.

\subsection{Decentralization as a commitment device}

In most of the cases studied in this paper, there is no informational advantage to decentralization: a federal government with sufficient information to design optimal transfers could simply implement the optimal (though possibly non-uniform) tax rates directly through a unitary system of government. Thus the case for decentralization must rest on other grounds. One motivation frequently pointed to in the literature is the "market-preserving" role of federalism (Qian and Weingast, 1997; Kehoe, 1989): in the presence of a variety of political failures, inter-jurisdictional competition places constraints on the powers of government that may be desirable. Of course, unfettered competition among governments is unlikely to be optimal in such circumstances; here we argue that equalization grants will also be required.

To make this point, we consider a problem of commitment failure in capital taxation. The setup of the model is the same as in Section 3, but with identical tastes and technologies for simplicity, and with a change in the order of moves. Now, tax rates are chosen after investors have made their savings decision; investments are irreversible but are freely mobile among regions of the federation after tax rates have been announced.

With this timing, governments perceive the elasticity of capital supply to be zero when tax rates are chosen. Lemma 1 shows that a central government with powers of taxation would impose a uniform tax in all regions at the rate $t=b^{\prime-1}(1) / s$. Comparing the full commitment optimal tax (19) shows that taxes would be too high and, in equilibrium, savings would be too low.

Now suppose that the central government can commit to transfer its tax powers to the regions, and to an equalization formula, prior to investments being sunk. From the perspective of regional governments, the aggregate supply of capital will still be fixed but mobile among regions. Using (5), the perceived elasticity of each region's tax base at any symmetric tax vector is

$$
\frac{\partial k_{i}^{*}}{\partial t_{i}}=\frac{N-1}{N} \phi^{\prime}
$$

Likewise, the marginal equalization transfer is

$$
\frac{\partial T_{i}^{E}}{\partial t_{i}}=t \frac{\partial k_{i}^{*}}{\partial t_{i}}
$$

Suppose therefore that the federal government had committed to equalize some fraction $\alpha$ of tax base differences. The first-order conditions (8) describing Nash equilibrium tax rates become

$$
k_{i}=b^{\prime}(g)\left(k_{i}+(1-\alpha) t \frac{N-1}{N} \phi^{\prime}\right)
$$


The first-order conditions (13) characterizing optimal tax rates under full commitment are unchanged, but under our symmetry assumptions they simplify to

$$
k_{i}=b^{\prime}\left(k_{i}+t \frac{s^{\prime} \phi^{\prime}}{s^{\prime}-\phi^{\prime}}\right)
$$

The two expressions are equivalent when

$$
1-\alpha=\frac{N}{N-1} \frac{e_{s}}{e_{s}+e_{d}}
$$

As the number of regions $N$ grows large, the optimal equalization formula approaches that of the full commitment case. For finite $N$, however, the federal government should equalize a smaller fraction of capacity differences, in order to counteract the tendency of regional governments to perceive tax base elasticities as smaller than they actually are. In fact, the optimal fraction in (23) is negative whenever

$$
e_{s}>(N-1) e_{d}
$$

As $e_{s} \rightarrow \infty$ (the case of a small open economy), $\alpha$ approaches its lower bound $-1 /(N-1)$.

\subsection{Regional population differences}

While partial equalization can implement the utilitarian optimum with elastic saving, when jurisdictions differ in taste for the public good, or (multiplicative) in technology, the equalization must be supplemented by lump-sum grants, which vary with a jurisdiction's characteristics. However, there is one case in which partial equalization alone is sufficient, even when jurisdictions differ in at least one respect. Suppose that each jurisdiction has the same tastes and technology, but that the jurisdictions have different population. In this case, not only is the Nash equilibrium inefficient in the absence of transfers, it also involves tax rates differing among jurisdictions. ${ }^{10}$ In this case, then, there are some inequalities for transfers to equalize.

Modifying slightly the notation of the previous sections, let $k_{i}$ and $g_{i}$ denote the per capita capital stock and public goods consumption in jurisdiction $i$. Let $n_{i}$ denote the population of the jurisdiction, relative to the average, so that $\sum_{i} n_{i}=N$. The utilitarian optimum is now $\sum_{i} n_{i}\left[v_{i}\left(k_{i}^{*}, r^{*}\right)+\right.$ $\left.b_{i}\left(g_{i}\right)\right]$. Maximizing this subject to the aggregate budget constraint $\sum_{i} n_{i}\left(t_{i} k_{i}^{*}-g_{i}\right)=0$ leads to the first-order conditions (10) and

$$
n_{i} k_{i}=\mu\left[n_{i} k_{i}+\sum_{j} n_{j} t_{j} \frac{\partial k_{j}^{*}}{\partial t_{i}}\right]
$$

Now the effect of a jurisdiction's tax rate on the net rate of return, obtained from differentiation of the aggregate capital market clearing condition $S\left(r^{*}\right)=\sum_{i} n_{i} \phi_{i}\left(r^{*}+t_{i}\right)$ is ${ }^{11}$

$$
\frac{\partial r^{*}}{\partial t_{i}}=\frac{n_{i} \phi_{i}^{\prime}\left(r^{*}+t_{i}\right)}{S^{\prime}\left(r^{*}\right)-\sum_{j} n_{j} \phi_{j}^{\prime}\left(r^{*}+t_{j}\right)}
$$

In this more general environment, Lemma 2 continues to hold: in particular, the optimal tax system is uniform among jurisdictions when technologies are everywhere identical. But, if there

\footnotetext{
${ }^{10}$ See Wilson (1991), or Bucovetsky (1991).

${ }^{11}$ The expressions for the effect of a tax change on the equilibrium capital allocation defined in (5) and (6) continue to hold, with $\partial r^{*} / \partial t_{i}$ defined by equation (25) instead of (4).
} 
were no transfers among jurisdictions, then tax rates could not be equal in any Nash equilibrium: If $t_{i}=t_{j}$ and if $n_{i}>n_{j}$ then (using (6) and (25)) the right-hand side of the optimality condition (8) would be greater for the larger jurisdiction, while the left-hand sides of the equation would be the same. Thus larger jurisdictions levy higher taxes in a Nash equilibrium without transfers, since they internalize more of the effects of tax increases than do small regions.

The formulae for equalization rules must also be modified slightly: Let $K=\sum_{i} n_{i} k_{i}$ denote the national total (not per capita) tax base. Equation (13) defines each government's per capita entitlement, where the national weighted-average tax rate is now $\bar{t}=\sum_{i} n_{i} t_{i} k_{i} / K$ and the per capita tax base is $\bar{k}=K / N$. Similarly, the revenue-sharing representation of the formula (14) holds where $R=\sum_{i} n_{i} t_{i} k_{i}^{*}$ is national total revenue. With these definitions, the expression (15) for the marginal equalization grant continues to hold. We then have the following result.

Proposition 4 If jurisdictions differ in population, but not in tastes or technologies, then the utilitarian optimum can be implemented by a system of partial equalization grants at the rate

$$
\alpha^{*} \equiv \frac{e_{d}}{e_{d}+e_{s}}
$$

Furthermore, no additional lump-sum transfers are required to achieve the optimum.

Proof. From Lemma 2, the tax rates in all jurisdictions should be equal at the optimum. When tax rates are equal, equation (24) becomes

$$
k_{i}=\mu\left[k_{i}+\frac{t}{n_{i}} \sum_{j} n_{j} \frac{\partial k_{j}^{*}}{\partial t_{i}}\right]=\mu\left[k_{i}+t \frac{\phi^{\prime} s^{\prime}}{s^{\prime}-\phi^{\prime}}\right]
$$

Also, when tax rates are equal,

$$
\frac{\partial T_{i}^{E}}{\partial t_{i}}=-t \phi^{\prime} \frac{N-n_{i}}{N}
$$

so that

$$
t \frac{\partial k_{i}^{*}}{\partial t_{i}}+\alpha \frac{\partial T_{i}^{E}}{\partial t_{i}}=t \frac{s^{\prime} \phi^{\prime}}{s^{\prime}-\phi^{\prime}}
$$

Under partial equalization at the rate $\alpha^{*}$, the Nash equilibrium has each jurisdiction choosing a tax rate such that equation (8) holds, with $T_{i}=\alpha^{*} T_{i}^{E}$. From equation (28), that means

$$
k_{i}=b^{\prime}\left(g_{i}\right)\left[k_{i}+t \frac{s^{\prime} \phi^{\prime}}{s^{\prime}-\phi^{\prime}}\right]
$$

when all tax rates are equal, so that the Nash equilibrium satisfies the optimality condition (26) under partial equalization at the rate $\alpha^{*}$. Since this equilibrium has each jurisdiction levy the same tax rate, therefore all jurisdictions have the same tax revenue per person, and thus the same level $g_{i}^{*}$ of public good provision per person. Equalizing all tax revenue at the rate $\alpha^{*}$ leads to a Nash equilibrium in which every jurisdiction levies the same tax rate, and where the tax revenue in each jurisdiction is the efficient $g_{i}^{*}$, whatever is the population distribution, thus proving the proposition. 


\section{Conclusion}

Intergovernmental transfer systems are most often designed to increase equality of fiscal opportunities among regions. Typically, in economic models, equity objectives such as this are achieved only at some cost in economic efficiency; but in the case of intergovernmental grants that conclusion may well be reversed. When tax bases are mobile among regions, local tax effort creates a positive fiscal externality for others, and so tax effort is undersupplied in equilibrium. In this context, our analysis shows that a particular simple and commonly used system of tax base equalization grants creates an incentive for local governments to enhance tax effort, to the benefit of all in the nation. Indeed, if tax bases are regionally mobile but fixed in the aggregate, an equalization grant induces efficient behaviour by all local governments, without recourse to dictates from a central government about what tax policies should be adopted locally.

While the simplicity of this result is striking, the general conclusion is as expected. There will always be some grant formula (and in fact there will be many) that decentralize the unitary optimum policies. More remarkable is that our result continues to hold (at least when the tax base elasticity is the same in all regions) regardless of the pattern of regional inequality and of population among regions, and regardless of nation-wide shocks to the demand for public goods and to the elasticity of capital demand. This reflects two features of an equalization grant based on the representative tax system. First, because transfers are proportional to the average of local tax rates, the incentives embodied in the system scale naturally to the magnitude of fiscal externalities, even as the size of government desired by citizens changes. Second, the marginal subsidy to local taxes provided by equalization is larger when a local jurisdiction's tax base deficiency is larger. Thus an equalization also naturally counters the pecuniary externality among regions that causes small and low-productivity regions to impose a lower tax rate than large and high-productivity ones. Again, in the model we consider, this offset is exact: an equalization grant precisely internalizes both the fiscal and pecuniary externalities facing all regions.

Equalization grants therefore achieve "robust" implementation of optimal tax policies in a federation, while other grant formulas would not. This fact might explain the apparent popularity of equalization grants throughout the world, compared to other redistributive transfer systems.

The results just described apply only in the case that the nation-wide tax base is unaffected by coordinated national tax increases. When taxes also have distortionary effects at the national level, our conclusions are modified. A system of partial equalization grants can then decentralize optimal taxes, where the fraction of base deficiencies to be equalized is the same for all regions and equal to the fraction of national tax increases that are shifted backward to factor suppliers. In this case, however, a standard tradeoff between equity and efficiency is restored: without supplementary lump-sum grants, an equalization system that provides efficient incentives would leave some tax base inequalities unaddressed, whereas a fully equalizing transfer system would induce excessive local taxation.

\section{Appendix}

Proof of Lemma 1. Given that the aggregate capital stock $K$ is fixed, and the concavity of the production functions $f_{i}\left(k_{i}\right)$, aggregate output $\sum_{j} f_{j}\left(k_{j}\right)$ is maximized if and only if the tax rates are equal across all jurisdictions. So the central government can always improve upon any policy in which tax rates are not all equal; if $t=\left(t_{1}, t_{2}, \ldots t_{N}\right)$ is any vector of tax rates, set

$$
t_{1}^{\prime}=t_{2}^{\prime}=\cdots=t_{N}^{\prime}=\left(\sum t_{j} k_{j}^{*}(t)\right) / K
$$


and the same tax revenue will be raised as with the tax vector $t$, so that the same vector of public good levels $g_{i}$ can be financed. Since the tax vector $t^{\prime}$ leads to a higher total level of output that does $t$, it leads to a higher value of

$$
\sum_{j} v\left(k_{j}^{*}, r\right)=\sum_{j}\left[f_{j}\left(k_{j}\right)-t_{j} k_{j}\right]
$$

Therefore, all tax rates must be equal at any solution to the central government's optimization problem. When the tax rates are equal, then the first order conditions (10) and (11) become $b_{i}^{\prime}\left(g_{i}\right)=$ 1 for all jurisdictions $i$, so that the unique solution is for each $g_{i}$ to equal $g_{i}^{*}$ and for each tax rate to equal $K /\left(\sum_{j} g_{j}^{*}\right)$.

Proof of Lemma 2. The first-order condition (11) for each $t_{i}$ can be written as

$$
\frac{1-\mu}{\mu} k_{i}=t_{i} \phi_{i}^{\prime}+\frac{\partial r^{*}}{\partial t_{i}} \sum_{j} t_{j} \phi_{j}^{\prime}
$$

where we have used the expressions (4)-(6) for the derivatives of the equilibrium investment levels. Summing these equations for all $i$ and noting $\sum_{i} k_{i}=S$ gives

$$
\frac{1-\mu}{\mu} S=\left(1+\sum_{i} \frac{\partial r^{*}}{\partial t_{i}}\right) \sum_{i} t_{i} \phi_{i}^{\prime}=\frac{S^{\prime}}{S^{\prime}-\sum_{i} \phi_{i}^{\prime}} \sum_{i} t_{i} \phi_{i}^{\prime}
$$

so that, when $S^{\prime}>0$,

$$
\sum_{i} t_{i} \phi_{i}^{\prime}=\frac{1-\mu}{\mu} \frac{S^{\prime}-\sum_{i} \phi_{i}^{\prime}}{S^{\prime}} S
$$

Substituting (31) into (29) and rearranging gives

$$
t_{i}=\frac{\mu-1}{\mu}\left(\frac{S}{S^{\prime}}-\frac{\phi_{i}}{\phi_{i}^{\prime}}\right)
$$

as desired.

Proof of Proposition 2. When productivity differences take the multiplicative form, Lemma 2 implies that optimal taxes are uniform. With uniform taxes, the marginal transfer (12) required to decentralize the optimum becomes

$$
\frac{\partial T_{i}^{*}}{\partial t_{i}}=t\left(\frac{\partial K^{*}}{\partial t_{i}}-\frac{\partial k_{i}^{*}}{\partial t_{i}}\right)+\frac{K}{\mu}\left(\frac{k_{i}}{K}-\frac{1}{N}\right) \frac{\partial r^{*}}{\partial t_{i}}
$$

whereas the marginal equalization transfer (15) is

$$
\frac{\partial T_{i}^{E}}{\partial t_{i}}=t\left(\frac{k_{i}}{K} \frac{\partial K^{*}}{\partial t_{i}}-\frac{\partial k_{i}^{*}}{\partial t_{i}}\right)-\left(\frac{k_{i}}{K}-\frac{1}{N}\right) \frac{\partial R}{\partial t_{i}}
$$

When production functions differ only by multiplicative constants, then (4) becomes

$$
\frac{\partial r^{*}}{\partial t_{i}}=-\frac{A_{i}}{N} \frac{e_{d}}{e_{s}+e_{d}}
$$


which implies

$$
\frac{\partial r^{*}}{\partial t} \equiv \sum_{j} \frac{\partial r^{*}}{\partial t_{j}}=-\frac{e_{d}}{e_{s}+e_{d}}
$$

and

$$
\begin{aligned}
\frac{k_{i}}{K} \frac{\partial K}{\partial t_{i}}-\frac{\partial k_{i}}{\partial t_{i}} & =\left(\frac{\partial K}{\partial t_{i}}-\frac{\partial k_{i}}{\partial t_{i}}\right)+\left(\frac{k_{i}}{K}-1\right) \frac{\partial K}{\partial t_{i}} \\
& =\left(N-A_{i}\right) \phi^{\prime} \frac{\partial r^{*}}{\partial t_{i}}+\left(A_{i}-N\right) s^{\prime} \frac{\partial r^{*}}{\partial t_{i}} \\
& =-\left(N-A_{i}\right)\left(s^{\prime}-\phi^{\prime}\right) \frac{\partial r^{*}}{\partial t_{i}} \\
& =\frac{1}{\partial r^{*} / \partial t}\left(\frac{\partial K}{\partial t_{i}}-\frac{\partial k_{i}}{\partial t_{i}}\right)
\end{aligned}
$$

Further, the planner's first-order condition for $t_{i}$ can be written

$$
\frac{\partial R}{\partial t_{i}}=\frac{k_{i}}{\mu}=\frac{K}{\mu} \frac{\partial r^{*} / \partial t_{i}}{\partial r^{*} / \partial t}
$$

Substituting the last two expressions into (33) gives

$$
\frac{\partial T_{i}^{E}}{\partial t_{i}}=-\frac{1}{\partial r^{*} / \partial t} t^{*}\left(\frac{\partial K}{\partial t_{i}}-\frac{\partial k_{i}}{\partial t_{i}}\right)-\frac{1}{\partial r^{*} / \partial t} \frac{K}{\mu}\left(\frac{k_{i}}{K}-\frac{1}{N}\right) \frac{\partial r^{*}}{\partial t_{i}}
$$

It follows from (33) and (36) that the marginal equalization grant is optimal if $T_{i}=\alpha T_{i}^{E}$, where

$$
\alpha=-\frac{\partial r^{*}}{\partial t}=\frac{e_{d}}{e_{s}+e_{d}}
$$

\section{References}

Brennan, G. and J. Buchanan, 1980, The Power to Tax (Cambridge University Press, New York).

Bucovetsky, S., 1991, Asymmetric tax competition, Journal of Urban Economics 30, 167-181.

Bucovetsky, S., M. Marchand, and P. Pestieau, 1998, Tax competition and revelation of preferences for public expenditure, Journal of Public Economics 44, 367-390.

Bucovetsky, S. and J. D. Wilson, 1991, Tax competition with two tax instruments, Regional Science and Urban Economics 21, 333-350.

Card, D. and A. Payne, 2002, School finance reform, the distribution of school spending, and the distribution of student test scores, Journal of Public Economics 83, 49-82.

DePater, J. A. and G. M. Myers, 1994, Strategic capital tax competition: A pecuniary externality and a corrective device, Journal of Urban Economics 36, 66-78.

Esteller-Moré, A. and A. Solé-Ollé, 2002, An empirical analysis of vertical tax externalities: The case of personal income taxation in Canada, International Tax and Public Finance 9. 
Figuieres, C., J. Hindriks, and G. Myles, 2001, Revenue sharing versus expenditure sharing, mimeo, CORE.

Hayashi, M. and R. Boadway, 2001, An empirical analysis of intergovernmental tax interaction: The case of business income taxes in Canada, Canadian Journal of Economics 34, 481-503.

Keen, M. J. and C. Kotsogiannis, 2002, Does federalism lead to excessively high taxes?, American Economic Review 92, 363-370.

Kehoe, P., 1989, Policy cooperation among benevolent governments may be undesirable, Review of Economic Studies 56, 289-296.

Köthenbürger, M., 2002, Tax competition and fiscal equalization, International Tax and Public Finance 9 .

Oates, W. E., 1972, Fiscal Federalism (Harcourt, Brace \& Jovanovich, New York).

Qian, Y. and B. Weingast, 1997, Federalism as a commitment to preserving market incentives, Journal of Economic Perspectives 11, 83-92.

Smart, M., 1998, Taxation and deadweight loss in a system of intergovernmental transfers, Canadian Journal of Economics 31, 189-206.

Tiebout, C., 1956, A pure theory of local expenditure, Journal of Political Economy 44, 416-424.

Wildasin, D. E., 1989, Interjurisdictional capital mobility: Fiscal externality and a corrective subsidy, Journal of Urban Economics 25, 193-212.

Wildasin, D. E., 1991, Income redistribution in a common labor market, American Economic Review 81, 757-774.

Wilson, J. D., 1986, A theory of interregional tax competition, Journal of Urban Economics 19, 296-315.

Wilson, J. D., 1991, Tax competition with interregional differences in factor endowments, Regional Science and Urban Economics 21, 423-451.

Wilson, J. D., 1999, Theories of tax competition, National Tax Journal 52, 269-304.

Zodrow, G. R. and P. Mieszkowski, 1986, Pigou, Tiebout, property taxation, and the underprovision of local public goods, Journal of Urban Economics 19, 356-370. 


\section{CESifo Working Paper Series}

699 Campbell Leith and Jim Malley, Estimated General Equilibrium Models for the Evaluation of Monetary Policy in the US and Europe, April 2002

700 Yin-Wong Cheung and Jude Yuen, Effects of U.S. Inflation on Hong Kong and Singapore, April 2002

701 Henry Tulkens, On Cooperation in Musgravian Models of Externalities within a Federation, April 2002

702 Ralph Chami and Gregory D. Hess, For Better or For Worse? State-Level Marital Formation and Risk Sharing, April 2002

703 Fredrik Andersson and Kai A. Konrad, Human Capital Investment and Globalization in Extortionary States, April 2002

704 Antonis Adam and Thomas Moutos, The Political Economy of EU Enlargement: Or, Why Japan is not a Candidate Country?, April 2002

705 Daniel Gros and Carsten Hefeker, Common Monetary Policy with Asymmetric Shocks, April 2002

706 Dirk Kiesewetter and Rainer Niemann, Neutral and Equitable Taxation of Pensions as Capital Income, April 2002

707 Robert S. Chirinko, Corporate Taxation, Capital Formation, and the Substitution Elasticity between Labor and Capital, April 2002

708 Frode Meland and Gaute Torsvik, Structural Adjustment and Endogenous Worker Recall Probabilities, April 2002

709 Rainer Niemann and Caren Sureth, Taxation under Uncertainty - Problems of Dynamic Programming and Contingent Claims Analysis in Real Option Theory, April 2002

710 Thomas Moutos and William Scarth, Technical Change and Unemployment: Policy Responses and Distributional Considerations, April 2002

711 Günther Rehme, (Re-)Distribution of Personal Incomes, Education and Economic Performance Across Countries, April 2002

712 Thorvaldur Gylfason and Gylfi Zoega, Inequality and Economic Growth: Do Natural Resources Matter?, April 2002

713 Wolfgang Leininger, Contests over Public Goods: Evolutionary Stability and the FreeRider Problem, April 2002

714 Ernst Fehr and Armin Falk, Psychological Foundations of Incentives, April 2002 
715 Giorgio Brunello, Maria Laura Parisi, and Daniela Sonedda, Labor Taxes and Wages: Evidence from Italy, May 2002

716 Marta Aloi and Huw Dixon, Entry Dynamics, Capacity Utilisation and Productivity in a Dynamic Open Economy, May 2002

717 Paolo M. Panteghini, Asymmetric Taxation under Incremental and Sequential Investment, May 2002

718 Ben J. Heijdra, Christian Keuschnigg, and Wilhelm Kohler, Eastern Enlargement of the EU: Jobs, Investment and Welfare in Present Member Countries, May 2002

719 Tapio Palokangas, The Political Economy of Collective Bargaining, May 2002

720 Gilles Saint-Paul, Some Evolutionary Foundations for Price Level Rigidity, May 2002

721 Giorgio Brunello and Daniela Sonedda, Labor Tax Progressivity, Wage Determination, and the Relative Wage Effect, May 2002

722 Eric van Damme, The Dutch UMTS-Auction, May 2002

723 Paolo M. Panteghini, Endogenous Timing and the Taxation of Discrete Investment Choices, May 2002

724 Achim Wambach, Collusion in Beauty Contests, May 2002

725 Dominique Demougin and Claude Fluet, Preponderance of Evidence, May 2002

726 Gilles Saint-Paul, Growth Effects of Non Proprietary Innovation, May 2002

727 Subir Bose, Gerhard O. Orosel, and Lise Vesterlund, Optimal Pricing and Endogenous Herding, May 2002

728 Erik Leertouwer and Jakob de Haan, How to Use Indicators for 'Corporatism' in Empirical Applications, May 2002

729 Matthias Wrede, Small States, Large Unitary States and Federations, May 2002

730 Christian Schultz, Transparency and Tacit Collusion in a Differentiated Market, May 2002

731 Volker Grossmann, Income Inequality, Voting Over the Size of Public Consumption, and Growth, May 2002

$732 \mathrm{Yu}-\mathrm{Fu}$ Chen and Michael Funke, Working Time and Employment under Uncertainty, May 2002

733 Kjell Erik Lommerud, Odd Rune Straume, and Lars Sørgard, Downstream Merger with Oligopolistic Input Suppliers, May 2002 
734 Saku Aura, Does the Balance of Power Within a Family Matter? The Case of the Retirement Equity Act, May 2002

735 Sandro Brusco and Fausto Panunzi, Reallocation of Corporate Resources and Managerial Incentives in Internal Capital Markets, May 2002

736 Stefan Napel and Mika Widgrén, Strategic Power Revisited, May 2002

737 Martin W. Cripps, Godfrey Keller, and Sven Rady, Strategic Experimentation: The Case of Poisson Bandits, May 2002

738 Pierre André Chiappori and Bernard Salanié, Testing Contract Theory: A Survey of Some Recent Work, June 2002

739 Robert J. Gary-Bobo and Sophie Larribeau, A Structural Econometric Model of Price Discrimination in the Mortgage Lending Industry, June 2002

740 Laurent Linnemer, When Backward Integration by a Dominant Firm Improves Welfare, June 2002

741 Gebhard Kirchgässner and Friedrich Schneider, On the Political Economy of Environmental Policy, June 2002

742 Christian Keuschnigg and Soren Bo Nielsen, Start-ups, Venture Capitalits, and the Capital Gains Tax, June 2002

743 Robert Fenge, Silke Uebelmesser, and Martin Werding, Second-best Properties of Implicit Social Security Taxes: Theory and Evidence, June 2002

744 Wendell Fleming and Jerome Stein, Stochastic Optimal Control, International Finance and Debt, June 2002

745 Gene M. Grossman, The Distribution of Talent and the Pattern and Consequences of International Trade, June 2002

746 Oleksiy Ivaschenko, Growth and Inequality: Evidence from Transitional Economies, June 2002

747 Burkhard Heer, Should Unemployment Benefits be Related to Previous Earnings?, July 2002

748 Bas van Aarle, Giovanni Di Bartolomeo, Jacob Engwerda, and Joseph Plasmans, Staying Together or Breaking Apart: Policy-makers' Endogenous Coalitions Formation in the European Economic and Monetary Union, July 2002

749 Hans Gersbach, Democratic Mechanisms: Double Majority Rules and Flexible Agenda Costs, July 2002

750 Bruno S. Frey and Stephan Meier, Pro-Social Behavior, Reciprocity or Both?, July 2002

751 Jonas Agell and Helge Bennmarker, Wage Policy and Endogenous Wage Rigidity: A Representative View From the Inside, July 2002 
752 Edward Castronova, On Virtual Economies, July 2002

753 Rebecca M. Blank, U.S. Welfare Reform: What's Relevant for Europe?, July 2002

754 Ruslan Lukach and Joseph Plasmans, Measuring Knowledge Spillovers Using Patent Citations: Evidence from the Belgian Firm's Data, July 2002

755 Aaron Tornell and Frank Westermann, Boom-Bust Cycles in Middle Income Countries: Facts and Explanation, July 2002

756 Jan K. Brueckner, Internalization of Airport Congestion: A Network Analysis, July 2002

757 Lawrence M. Kahn, The Impact of Wage-Setting Institutions on the Incidence of Public Employment in the OECD: 1960-98, July 2002

758 Sijbren Cnossen, Tax Policy in the European Union, August 2002

759 Chandima Mendis, External Shocks and Banking Crises in Developing Countries: Does the Exchange Rate Regime Matter?, August 2002

760 Bruno S. Frey and Lars P. Feld, Deterrence and Morale in Taxation: An Empirical Analysis, August 2002

761 Lars Calmfors and Åsa Johansson, Nominal Wage Flexibility, Wage Indexation and Monetary Union, August 2002

762 Alexander R. W. Robson and Stergios Skaperdas, Costly Enforcement of Property Rights and the Coase Theorem, August 2002

763 Horst Raff, Preferential Trade Agreements and Tax Competition for Foreign Direct Investment, August 2002

764 Alex Cukierman and V. Anton Muscatelli, Do Central Banks have Precautionary Demands for Expansions and for Price Stability? - Theory and Evidence, August 2002

765 Giovanni Peri, Knowledge Flows and Knowledge Externalities, August 2002

766 Daniel Friedman and Nirvikar Singh, Equilibrium Vengeance, August 2002

767 Sam Bucovetsky and Michael Smart, The Efficiency Consequences of Local Revenue Equalization: Tax Competition and Tax Distortions, August 2002 